\title{
Diferenças de gênero no desenvolvimento sexual: Integração dos paradigmas biológico, psicanalítico e evolucionista
}

\author{
Luciana Parisotto* \\ Katia Beirão de Almeida Guaragna** \\ Maria Cristina Vasconcelos*** \\ Matias Strassburger ${ }^{* * * *}$ \\ Mônica Horikawa Zunta***** \\ Wilson Vieira Melo*****
}

“...embora as várias ciências realmente ocupem níveis diferentes, elas formam parte de uma única estrutura conexa. A unidade desta estrutura é cimentada pelas relações entre as partes...O empreendimento da ciência envolve a investigação destas leis em todos os níveis, ao mesmo tempo que trabalha também, de cima para baixo e de baixo para cima, para construir escadas entre eles".

(Gell-Mann,M., 1996)

Trabalho apresentado no XVI Ciclo de Avanços em Clínica Psiquiátrica. * Médica Psiquiatra, Membro Efetivo da SPRS, Mestre em Ciências do Comportamento.

** Médica Ginecologista e Obstetra.

*** Médica Psiquiatra, Mestre em Antropologia Social pela UFRGS. Candidata do Instituto de Psicanálise da SPPA.

**** Médico Psiquiatra, Membro Efetivo da SPRS, Candidato Graduado do Instituto de Psicanálise da SPPA.

***** Médica com Curso de Especialização em Psiquiatria no Hospital São Lucas da PUCRS.

****** Psicólogo Clínico, Mestrando em Psicologia Clínica- PUCRS.

\section{INTRODUÇÃO}

Para Freud, o instinto de vida era representado pela energia pulsional chamada Libido; para Darwin, pelo Imperativo Reprodutivo: o impulso básico de deixar cópias de melhor qualidade possível. Constituem-se de uma mesma força, com diferentes paradigmas para compreendê-la.

Na física moderna, a busca de teorias unificadoras das diferentes energias encontradas no universo, desde as forças de ligação de minúsculas partículas energéticas como os quarks, até as energias mais densas, como a gravidade e o eletromagnetismo, tem sido uma meta extremamente atual na pesquisa científica. Do ponto de vista antropocêntrico, pesquisas estão sendo realizadas na ontogenia, na filogenia, na fisiologia e sociobiologia, aqui também se almejando uma teoria unificadora. Entretanto, há necessidade de se avaliar cientificamente possíveis pontes entre os diferentes aspectos da vida humana.

Em relação à energia que motiva o desejo sexual, muitas observações já foram feitas, mas a união delas ainda é bastante obscura, pois

Recebido em 24/01/2003. Revisado em 24/01/2003. Aprovado em 11/03/2003. 
nas áreas consideradas menos exatas como a da psicologia, os mecanismos não são conhecidos, tampouco os seus processos subjacentes. O estudo é descritivo e fenomenológico, somando-se ainda o fato da complexidade das interações dos indivíduos de sexos diferentes um com outro e com o meio ambiente, a capacidade dinâmica de adaptação destes aliada à aprendizagem e a randomicidade, sempre presente nos fenômenos naturais.

O objetivo deste grupo de estudo foi descrever as diferenças de gênero no desenvolvimento sexual humano, à luz dos vértices biológico, psicanalítico e evolucionista, buscando-se pontes de conexão entre estes paradigmas, para uma visão mais integrada do processo de ser masculino ou feminino.

\section{PARADIGMA EVOLUCIONISTA}

\section{Interpretação Evolutiva de Libido}

Podemos encarar os seres vivos, aqui não apenas como indivíduos e sim como espécie, como tendo uma programação (instinto) básica de sobrevivência e perpetuação da espécie, como um programa ou sistema operacional, fazendo-se uma analogia com a linguagem da computação. A vida tem sido definida como a soma de propriedades pelas quais um organismo se desenvolve e se reproduz, adaptando-se ao seu meio ambiente, qualidades essas que o diferem de corpos orgânicos mortos ou de corpos inorgânicos. Estes seres vivos (ou Sistemas Adaptativos Complexos), desde a mais simples forma orgânica até a complexidade observada nos primatas, seguem sua evolução sob a égide do Imperativo Reprodutivo: deixar cópias gênicas da melhor qualidade possível. Essa programação básica de fato está impressa em todos os seres vivos.

Diferenças de Gênero: por que dois sexos e o porquê das suas diferenças?

Do ponto de vista evolucionista, a existência de dois sexos e de suas características e funções distintas é considerada apenas mais uma tática em prol da sobrevivência e da perpetuação da espécie.

No início da evolução da vida, os seres vivos reproduziam-se basicamente por partenogênese. A reprodução sexual foi uma melhoria evolutiva, com objetivo de gerar indivíduos com características levemente distintas de seus ancestrais. Essas novas combinações garanti- genéticas aos indivíduos, para que alguns desses pudessem adaptar-se às intempéries e pressões do meio ambiente e pudessem repassar a herança genética (as informações básicas da vida) para as futuras gerações.

\section{Seleção Natural}

A Seleção Natural corresponde exatamente às pressões seletivas, do meio ambiente, exercidas sobre os seres vivos, que então precisaram ajustar-se e adaptar-se para sobrevivência ${ }^{1}$.

Como exemplo, tomemos o tipo de bico de alguns pássaros (tentilhão). Em determinados ambientes, o bico curto pode ser menos adaptativo na coleta de alimentos. O pássaro que apresentar este tipo de bico vai ter mais dificuldade de se alimentar, morrendo com mais freqüência do que outra ave de mesma espécie, mas de bico longo. A seleção natural favorece o animal de bico longo, e quem o possuir sobreviverá mais e terá a chance de passar seus genes e suas características mais adaptadas para as futuras gerações.

\section{Seleção Sexual}

A reprodução sexual requer a união de gametas masculinos e femininos (e de seus hospedeiros) para a procriação. Mas como identificar e selecionar o melhor gameta/ hospedeiro para união?

As evidências sugerem que a seleção sexual não ocorre ao acaso, e sim sob o domínio de algumas leis e mecanismos psicológicos dependentes de um aparelho que evoluiu segundo as regras universais que geram todos os sistemas biológicos (Seleção Sexual). Aparentemente, sentimos desejo sexual por determinados sujeitos. Podemos nos enganar ao tomar essa experiência consciente como explicação última de nossa própria conduta, ainda quando a experiência consciente não seja mais que "uma cortina de fumaça" construída para acomodar as respostas psicológicas (mecanismos psicológicos que ajustam comportamentos específicos) de nossos ancestrais, bem sucedidos em sua reprodutibilidade ${ }^{2}$.

A teoria Darwiniana propõe que só há seleção sexual quando existe uma variabilidade de características entre indivíduos de mesma espécie que possibilite seleção de um em detrimento de outro. Se todos fossem similares, não haveria razão para seleção ${ }^{3}$. Esses diferentes traços podem ser selecionados e repassados a futuras gerações de forma desigual. Alguns in- 
divíduos, justo por possuírem determinadas características que sinalizam maior capacidade de sobrevivência em um contexto específico, podem deixar maior número de descendentes ao serem mais selecionados por seus pares. Quanto maior a capacidade de sinalizar boa qualidade, maior chance de ser selecionado e de ter grande número de filhotes, aumentando a probabilidade de transmitir para as futuras gerações tais características adaptativas.

A seleção sexual é responsável, então, pela evolução de características que dão aos organismos vantagens reprodutivas, em contraste com as vantagens de sobrevivência. Assim, pode-se explicar por que alguns traços, como ornamentos coloridos em pássaros ou plumagens coloridas da cauda de pavões, são preferidos pelas fêmeas, apesar de não indicarem nenhuma vantagem adaptativa para a sobrevivência. A seleção natural por si só teria excluído tais características, se não fossem de alguma forma importantes. A sinalização da qualidade de um indivíduo como parceiro sexual está vinculada a esses sinais ${ }^{1}$. Por exemplo, a plumagem colorida de um pavão macho chama muito mais atenção de predadores que a plumagem mais opaca. Esperar-se-ia que tal característica não passasse para as gerações futuras, por indicar uma desvantagem desse indivíduo na sobrevivência, talvez morto antes da idade reprodutiva. No entanto, os machos que sobrevivem apesar do ornamento vistoso demonstram muito mais valor reprodutivo (capacidades e resistência), pistas mais honestas de uma boa genética a ser transmitida para a prole.

O sexo ou a atividade sexual vem cumprindo, então, essa função adaptativa.

\section{Psicologia Evolucionista}

A psicologia Evolucionista é uma ciência nova que tem sua fundamentação na Sociobiologia, na Ecologia e nas Teorias da Evolução. Parte do princípio de que os padrões comportamentais são respostas motoras pré-estabelecidas que sofreram pressões da seleção natural e que influenciaram o comportamento social de membros da mesma espécie. Aqui não são os traços ou características físicas que são levados em consideração como primeiro plano para a Seleção Natural/Sexual, e sim os comportamentos e seus mecanismos psicológicos, sujeitos a essas mesmas pressões naturais.

Para compreender melhor como isso se processa, pensemos de forma análoga à problemática do bico dos pássaros, agora tomando o comportamento dos bebês como exemplo. Os bebês de nossa espécie mantêm padrões de respostas estereotipados para otimizar sua sobrevivência nos primeiros anos de sua existência, quando dependem exclusivamente de cuidados. Bebês com predisposição inata a sorrir e a fixar o olhar em seus cuidadores aumentam expressivamente suas chances de serem alimentados e cuidados, podendo se desenvolver e passar suas cópias genéticas adiante. Tal comportamento mostra-se vantajoso para sua sobrevivência, sendo favorecido pela seleção natural ${ }^{4}$.

Da mesma forma que as combinações de genes são criadas, os traços que elas determinam e os comportamentos padronizados (ou mecanismos psicológicos que levam a um comportamento estereotipado - estratégia - expressões cognitivas ou afetos) também o são: criase uma variedade de combinações a serem selecionadas, algumas se tornam viáveis e proliferam; outras, se perdem, desaparecendo do código genético em algumas gerações.

\section{Teoria de Investimento Parental}

O investimento parental pode ser definido como qualquer tempo, esforço ou energia gastos para garantir a sobrevivência de um filhote às custas de outras formas de investimento, incluindo esforços alocados para competição por outros parceiros. Nos mamíferos, particularmente nos seres humanos, os machos podem investir muito pouco na prole: apenas o esperma (produzido aos milhões), necessário para a inoculação e fertilização da fêmea. Já esta última faz um investimento bem mais significativo: tem poucos gametas e pode ter no máximo vinte e cinco filhotes durante toda a sua vida. Precisa manter-se por nove meses de gestação, além de investir em amamentação e desenvolvimento de cada filhote por alguns anos. Exatamente por esta assimetria é que o sexo que investir mais deve ser necessariamente mais discriminativo na seleção de seu par.

\section{Teoria das Estratégias Sexuais}

A seleção de parceiros sexuais entre homens e mulheres foi similar para muitos domínios, nos quais ambos os sexos defrontaram-se com os mesmos problemas adaptativos ao longo da história evolutiva. No entanto, dadas as diferenças reprodutivas entre eles do mínimo investimento parental em cada filhote, não seria de surpreender que machos e fêmeas de- 
senvolvessem e evoluíssem estratégias reprodutivas diferentes (mecanismos psicológicos padronizados) para lidar com tais problemas específicos, selecionando traços sexuais distintos $^{5,6}$. O homem tenderia a estratégias de curta duração, minimizando ao máximo o comprometimento com cada fêmea, tendo desejo e freqüência sexual aumentados e sendo capaz de detectar rapidamente sinais de disponibilidade ao sexo e fertilidade feminina. A fêmea buscaria relacionamentos mais duradouros para garantir a proteção e o investimento paterno nela e em sua prole, ou relacionamentos curtos com provedores de imediato retorno.

O objetivo final da estratégia sexual é o sucesso reprodutivo. Ela guia o esforço reprodutivo de ambos os sexos e é constituída: 1) por mecanismos psicológicos desenvolvidos para solucionar problemas adaptativos; 2) por suas diferentes manifestações comportamentais.

Três diferenças básicas universais entre os sexos foram detectadas na escolha de parceiros sexuais. Os homens tendem a valorizar mais do que as mulheres a aparência física e a juventude (critérios de saúde e fertilidade). Enquanto as mulheres, comparadas aos homens, valorizam mais as capacidades econômicas (critério de oferta de recursos) ${ }^{5}$. Isso não quer dizer que as mulheres não valorizem os aspectos físicos. Elas também o fazem, mas menos do que os homens. Tanto homens quanto muIheres selecionam pares por vários aspectos, dependendo da estratégia de curta ou longa duração, podendo valorizar mais alguns aspectos do que outros ${ }^{7}$.

Novas teorias de seleção sexual sugerem que a mulher pode escolher de acordo com as demandas do meio ambiente. Se existem muitas ameaças naturais, como doenças (em países subdesenvolvidos), ela escolheria pela aparência e simetria do homem, buscando melhor qualidade genética e resistência física (bonsgenes). No caso da demanda ser de recursos, a prioridade de preferência seria por parceiros bons provedores ${ }^{8,9}$

Alguns outros autores compararam as leis da economia com o mercado sexual, sugerindo que ambos sexos escolhem seus parceiros de acordo com os seus próprios valores reprodutivos em um determinado nicho. Homens de boa genética (simétricos) e com recursos poderiam selecionar mais tranqüilamente suas parceiras comparados aos que oferecem menos atributos. Também o número de indivíduos de cada sexo poderia afetar o valor reprodutivo; como por exemplo, em uma localidade com poucos homens, onde as mulheres, por mais alto valor reprodutivo que possam ter, têm de disputar a companhia de alguns poucos machos existentes ${ }^{8,10}$.

\section{PARADIGMA BIOLÓGICO}

O desenvolvimento humano inicia-se na fecundação, quando o espermatozóide une-se ao óvulo para formar um organismo unicelular, o zigoto, célula que marca o início de cada um de nós como indivíduo único ${ }^{11}$.

O zigoto contém os genes duplicados provenientes da mãe e do pai e se transforma progressivamente em um ser humano multicelular através de divisão, migração, crescimento e diferenciação das células. Para que ocorra a fecundação, são necessárias células germinativas especializadas, os gametas, em cujo processo de formação e desenvolvimento o número cromossômico é reduzido à metade, sendo a forma destas células alterada.

Em relação às mulheres, tal processo é chamado de ovogênese e consiste na transformação de ovogônias em óvulos. No início da vida fetal, as ovogônias proliferam por divisões mitóticas, sendo que antes do nascimento aumentam de volume para se constituírem em ovócitos primários, os quais iniciam a primeira divisão meiótica ainda antes do nascimento; porém, tal divisão só será completada após a puberdade, quando a maturidade sexual é alcançada e os ciclos reprodutivos iniciados. Nenhum ovócito primário é formado após o nascimento; em contraposição, os homens continuam a produzir espermatócitos após a puberdade.

No indivíduo masculino, este processo é chamado de espermatogênese, ou seja, uma seqüência de eventos onde espermatogônias (46 xy), que permanecem "adormecidas" nos túbulos seminíferos dos testículos desde o período fetal, começam a crescer em número na puberdade, por volta dos 13 anos de idade, em conseqüência da estimulação dos hormônios gonadotróficos da adeno-hipófise, prosseguindo durante toda a vida. Após várias divisões mitóticas e meióticas, cada espermatogônia dará origem a quatro espermatozóides (23x, 23x, 23y, 23y). A importância dessas divisões é que cada espermátide formada possui apenas vinte e três cromossomos, ou seja, metade dos genes da espermatogônia original. Por conseguinte, o espermatozóide que irá fertilizar o óvulo fornecerá metade do material genético, enquanto o óvulo contribuirá com a outra metade. 
A metade dos espermatozóides contém o cromossomo y, tornando-se espermatozóides masculinos, e a outra metade, ox, desta forma espermatozóides femininos. O sexo do descendente é determinado pelo tipo de espermatozóide que irá fertilizar o óvulo (que é sempre 23x); logo, é o gameta paterno que determina o sexo da prole ${ }^{12}$.

Ocorrendo a fecundação do óvulo pelo espermatozóide $x$ ou y, ainda na trompa de Falópio, iniciam-se as divisões celulares. Uma célula (o zigoto) dará origem a duas células, que formarão quatro células ainda indiferenciadas, e assim sucessivamente, até sua chegada no útero, onde o embrião irá nidar (de 8 a 11 dias após a fecundação). Neste momento, as células indiferenciadas, denominadas totipotentes, iniciam suas diferenciações, dando origem aos diversos tipos de tecidos e sistemas, em momentos distintos. Somente a partir da quinta semana de gestação é que ocorre a diferenciação sexual. Antes disso, as gônadas são ditas primitivas ou indiferenciadas, podendo originar ovários ou testículos.

É a presença do cromossomo y que determina a diferenciação das gônadas primitivas em testículos; na sua ausência, ocorrerá sempre diferenciação em ovários. No embrião também estão presentes os ductos de Muller e os ductos de Wolff, os quais originarão, respectivamente, a genitália interna feminina e masculina. A diferenciação biológica processa-se sempre no sentido feminino, independente dos genes $X$ ou $Y$. É a presença do hormônio testosterona que desvia o desenvolvimento para uma diferenciação masculina.

Após a diferenciação sexual e a formação dos testículos, estes iniciam a produção de testosterona já na oitava semana gestacional. Durante a vida fetal, os testículos são estimulados pela gonadotrofina coriônica secretada pela placenta, estimulando a secreção de quantidades moderadas de testosterona, sendo que tal secreção persiste até cerca de três semanas após o nascimento A presença de testosterona irá promover o desenvolvimento dos canais de Wolff, a partir dos quais se formarão o epidídimo, o canal deferente e a vesícula seminal. Junto com a testosterona, ocorre a produção do FIM (Fator Inibidor de Muller), o qual impede o desenvolvimento dos ductos de Muller, determinando a atrofia dos mesmos.

Com a ausência do cromossomo y e conseqüentemente com a ausência de testosterona e do FIM, os ductos de Wolff não se desenvolvem, entram em atrofia e dão lugar ao desenvolvimento dos ductos de Muller, a partir dos quais se formam as trompas, o útero e os $2 / 3$ superiores da vagina. Convém ressaltar que não há secreção hormonal por parte do ovário para que ocorra a diferenciação no sentido feminino. Ela tende a ocorrer naturalmente.

Quanto à genitália externa, esta também apresenta uma fase indiferenciada e bipotencial, formando-se a partir do tubérculo genital, seio urogenital e dobras lábio-escrotais, as quais, na presença de testosterona (endógena ou exógena), originarão, respectivamente, pênis, escroto e uretra peniana; na ausência de testosterona, ocorrerá, respectivamente, a formação do clitóris, lábios vulvares, uretra e terço inferior da vagina. Há uma perfeita correspondência entre as genitálias masculinas e femininas.

$\mathrm{Na}$ infância, a menina não apresenta oscilações hormonais significativas aproximadamente até os 8-9 anos de idade, e o menino, até a idade de 10 a 13 anos, quando tem início a puberdade.

Grande parte do controle das funções sexuais começa em ambos os sexos com a secreção do hormônio liberador das gonadotrofinas ( $\mathrm{GnRH}$ ) pelo hipotálamo, o qual estimula a secreção pela adeno-hipófise de dois hormônios: $\mathrm{LH}$ e FSH.

No homem o FSH estimula a espermatogênese, e o LH estimula a secreção de testosterona pelos testículos; sua secreção é baixa nos meninos até por volta dos 11 anos, quando então aumenta rapidamente pelo estímulo dos hormônios gonadotróficos da adeno-hipófise. A testosterona é responsável pelo desenvolvimento, crescimento e manutenção da funcionalidade da genitália masculina e pelas características sexuais secundárias, determinando um aumento de até oito vezes no tamanho do pênis, da bolsa escrotal e dos testículos antes dos 20 anos de idade. Também se observa seu efeito sobre a distribuição dos pêlos corporais de forma masculina; sobre a voz, já que induz a uma hipertrofia da laringe e como efeito uma voz dissonante e "rachada", que gradualmente se torna uma voz grave típica masculina, bem como o aumento da espessura da pele em todo o corpo e desenvolvimento de acne, o desenvolvimento da musculatura, que aumenta uma média de $50 \%$ a mais em relação à mulher. Tem efeito sobre o crescimento ósseo e retenção de cálcio $^{12}$. A idade da espermarca (primeira ejaculação) é muito variável e não se relaciona com a fase de maturação. A puberdade masculina termina, em geral, por volta dos 16 anos. Posteriormente os testículos humanos continuam a produzir a testosterona para manter a 
libido até o fim da vida, também estimulando comportamento mais agressivo, mais territorial e mais competitivo, necessário para a sobrevivência da espécie, juntamente com um papel vital na motivação sexual e aspectos mais decorativos das características masculinas para atrair as fêmeas de sua espécie ${ }^{13}$.

$\mathrm{Na}$ menina, o amadurecimento do SNC faz com que o hipotálamo, de forma pulsátil, libere o GnRH (hormônio liberador de gonadotrofinas), o qual vai estimular a hipófise a produzir FSH (hormônio folículo estimulante) e LH (hormônio luteinizante), dando início à puberdade. Estes hormônios vão agir nos ovários, estimulando o desenvolvimento dos folículos primordiais a partir dos quais serão produzidos hormônios androgênicos (testosterona e androstenediona) e hormônios estrogênicos (estradiol e estrona). A produção estrogênica por parte do ovário vai promover o desenvolvimento dos chamados caracteres sexuais secundários. Na maioria das meninas, a primeira manifestação é o aparecimento do broto mamário, chamado Telarca, e ocorre geralmente entre os 9-10 anos. Nessa mesma fase, tem início o estirão puberal, que atingirá seu máximo por volta dos 11 anos de idade.

A supra-renal também contribui na produção androgênica, fazendo com que, em algumas meninas (a minoria), a chamada adrenarca, caracterizada pelo surgimento de pêlos pubianos, anteceda o aparecimento do broto mamário. Posteriormente, surgem os pêlos axilares, bem como o aumento do peso corporal e distribuição de gordura tipicamente feminina. Após todo esse amadurecimento corporal, e com níveis hormonais capazes de estimular o endométrio, ocorrerá a primeira menstruação, a chamada Menarca, ao redor dos 12 anos de idade, momento em que também ocorre uma desaceleração do crescimento.

A menarca não caracteriza o fim da puberdade, mas sim o início de seu último estágio, que pode durar até um ou dois anos, ou seja, até que se estabeleçam os ciclos ovulatórios, caracterizados pela sua regularidade, evidenciando a maturidade do eixo hipotálamo-hipófiseovário. A partir deste momento, se tudo evoluir normalmente e o eixo hipotálamo-hipófise-ovário não for bloqueado (através de anticoncepcionais hormonais, por exemplo), ocorrerá mensalmente nesta menina-mulher e durante sua vida adulta uma "preparação" para a gestação. Cada ciclo inicia no primeiro dia da menstruação, com níveis hormonais baixos, o que promove por "feedback" positivo a nível hipotalâ- atuará na hipófise, estimulando a produção de FSH. O FSH atuará no ovário, que aumentará progressivamente a produção de Estrogênio. Este hormônio irá provocar uma proliferação do endométrio no útero, tornando-o mais adequado à implantação do provável embrião. Os níveis crescentes de estrogênio atingem níveis críticos por volta da metade do ciclo, desencadeando uma liberação em pico do LH (hormônio Luteinizante), responsável pela ruptura do folículo e conseqüente liberação do óvulo, pronto para ser fecundado. Neste momento, o nível de estrogênio torna-se estável, em platô. O folículo roto forma o corpo lúteo, responsável pela produção de progesterona que, a nível uterino, vai bloquear o crescimento do endométrio, transformando-o em secretor rico em glicogênio, capaz de nutrir o embrião logo após a nidação, até que se estabeleçam as formações vasculares responsáveis pelas trocas mãe-feto.

Entretanto, se a fecundação não ocorrer, os níveis de estrogênio e de progesterona caem bruscamente, provocando a menstruação, com a qual se inicia um novo ciclo e mais uma "tentativa"...

Diferentemente das outras espécies de mamíferos, as mulheres não ficam no cio quando ovulam, mas apresentam alterações comportamentais mais sutis, como por exemplo, na linguagem corporal e no contato visual, os quais informam aos homens que estão querendo ter as mesmas relações sexuais.

Também um outro papel do estrogênio é o de manter as características sexuais secundárias (sinalizações de fertilidade), que as tornam mais atraentes para os homens, juntamente com um comportamento menos agressivo e territorial e mais maternal ${ }^{13}$. Durante a fase estrogênica, ocorre a liberação dos chamados ferormônios, que são substâncias aromáticas produzidas pelas células da genitália feminina os quais despertam desejo sexual no macho; assim, esse odor liberado pelos amantes pode ser, além de excitante, bastante prazeroso tanto para os homens quanto para as mulheres e parece também estar relacionado com a escoIha do parceiro.

Como ocorre no homem, a testosterona também tem um papel na manutenção do impulso sexual nas mulheres, sendo que sua secreção eleva-se na puberdade, mantendo-se constante com pequenas flutuações durante 0 ciclo menstrual.

Os ciclos menstruais mantêm-se de forma regular até por volta dos 45 anos, quando inicia o período do climatério, com o esgotamento dos folículos ovarianos e diminuição da produ- 
ção ovariana de hormônios. Com esta redução, há um aumento importante das gonadotrofinas na tentativa de estimular os ovários que já não respondem mais. Esta fase caracteriza-se, na maioria das vezes, inicialmente por ciclos menstruais irregulares (climatério pré-menopáusico), até a parada completa das menstruações. A menopausa (data da última menstruação, identificada de forma retroativa após um ano de amenorréia) é o marco que divide o climatério em pré e pós-menopáusico. O climatério é uma fase de transição da vida reprodutiva para a não reprodutiva.

No homem, a produção de testosterona persiste durante a maior parte da vida adulta, reduzindo de forma acentuada após os 50 anos de idade, chegando a atingir aos 80 anos um nível que corresponde a cerca de $20-50 \%$ do valor máximo já secretado. Todavia, a maioria dos homens começa a exibir uma redução lenta das funções sexuais entre os 40-50 anos, com uma média para o término das funções sexuais em torno dos 68 anos de idade, apesar da existência de grandes variações. Em um estudo realizado com homens saudáveis entre 45-75 anos, observou-se uma redução significativa no desejo, excitação e atividade sexual, bem como uma diminuição nos níveis de testosterona biodisponível e um aumento no $\mathrm{LH}$, sendo um determinante da redução da função sexual. Não foram evidenciadas, porém, diferenças quanto ao prazer e satisfação sexual ${ }^{14}$. Essa fase de declínio da função sexual relacionada à redução da secreção de testosterona é chamada de climatério masculino, a qual está associada a sintomas como ondas de calor, sufocação e distúrbios psíquicos semelhantes à menopausa feminina.

Os órgãos sexuais internos e externos de ambos os sexos, juntamente com a musculatura do assoalho pélvico e com várias outras estruturas do organismo, sofrem uma série de modificações mediadas pelo sistema neurovegetativo, simpático e parassimpático, ocasionando reações que constituirão o Ciclo da Resposta Sexual Humana, cujas fases são:

Desejo: nesta fase, sentidos como olfato, visão, audição conduzem os estímulos via córtex e sistema límbico, desencadeando a excitação. O impulso sexual feminino tem também uma base hormonal. Sabe-se que a testosterona é o hormônio responsável pela libido e que a progesterona tem um efeito antilibidinoso, o que explica as flutuações do desejo nas diversas fases do ciclo menstrual ${ }^{15}$. Os homens requerem um nível dez vezes maior de testosterona comparado às mulheres. A vasocongestão dos órgãos genitais prepara-os para as funções reprodutivas. O desejo sexual pode ser afetado em sua intensidade pelos níveis de testosterona, mas sugere-se clara predominância de determinantes psicossociais na excitação sexual humana.

Excitação: a vasocongestão difusa resulta em lubrificação e em edema vaginal nas mulheres. Nos homens, ocorre dilatação das artérias do pênis, aumentando o influxo, e o relaxamento dos músculos do corpo cavernoso impede o efluxo, resultando na ereção peniana.

Orgasmo: ocorrem espasmos reflexos, clônicos, prazerosos da musculatura genital. Nas mulheres, há uma expansão máxima do canal vaginal posterior, contração do terço anterior da vagina e contração do esfíncter externo do ânus, assim como também há uma predominância do lobo límbico, liberando neuro-transmissores que vão determinar reações extragenitais. Nos homens, a contração dos músculos lisos dos órgãos de reprodução internos acumula um bolus para ejacular na uretra posterior, enquanto as contrações dos músculos bulbocavernosos e ísquio-cavernosos impulsionam a ejaculação para o meato uretral externo ${ }^{15}$.

Resolução: neta fase, ocorre o retorno da genitália ao seu estado quiescente; há uma sensação de saciedade, a qual pode estar relacionada com a liberação simultânea de ocitocina em ambos parceiros sexuais. A ocitocina secretada pelo cérebro das mães e dos bebês, durante a amamentação, está relacionada com a ligação materno-fetal e também é secretada por ambos parceiros durante o ato sexual. Investigações neuroendócrinas têm mostrado uma associação entre a ocitocina, a excitação sexual e o orgasmo. Com isso, também se pode especular que essa liberação de ocitocina após a estimulação sexual e o orgasmo seja parcialmente responsável pela sensação de paz que se observa pós-coito, remanescente da expressão de tranqüilidade dos bebês após terem sido amamentados ${ }^{13}$.

\section{PARADIGMA PSICANALÍTICO}

A noção de feminilidade e masculinidade ultrapassa o sexo biológico do indivíduo. O desenvolvimento biológico ainda intra-útero, com a liberação hormonal de testosterona, promoverá uma diferenciação corporal no sentido masculino. Não ocorrendo esta liberação, o feto desenvolverá uma diferenciação feminina. O cérebro, então, tem uma tendência biológica para o desenvolvimento feminino ${ }^{16}$.

Entretanto, no desenvolvimento do indiví- 
duo, do ponto de vista do gênero a que ele pertence, este aspecto biológico é apenas um dos constituintes. Entram em jogo as representações mentais, não só das percepções inconscientes dos próprios pais, assim como a influência do ambiente e da cultura a que o indivíduo pertence ${ }^{17}$. Desta maneira, entendese a sexualidade do adulto como decorrente de um processo de desenvolvimento ordenado a partir de diversos aspectos, desde o biológico, atravessando o aprendizado cultural, até as representações mentais que estão perpassadas por conflitos referentes à situação edípica. É nesta área - dos conflitos, das representações mentais, das fantasias -, que está para além da objetividade e que está presente em toda atividade sexual, que a psicanálise tem oferecido sua maior contribuição.

Esta contribuição iniciou com Freud, quando este se deparou com a necessidade de entender e explicar os fatores causais das neuroses. A época era o final dos anos 1800 , e suas primeiras abordagens privilegiaram os pontos de vista fisiológico e químico.

Foi somente em 1896, no rascunho K, que houve uma primeira tentativa de abordar o tema da sexualidade sob um vértice mais psicológico. Neste trabalho, Freud ocupa-se em comparar a histeria, a neurose obsessiva e a paranóia, partindo do princípio de que em todas haveria uma etiologia sexual. Mesmo que nesta época a sexualidade infantil já ocupasse a mente de Freud, ainda era vista como algo latente, à espera de um fator traumático que a trouxesse à tona.

Falando a Fliess da sua desilusão com a teoria da sedução e na sua auto-análise, com a descoberta do complexo de Édipo, reconhece Freud que os impulsos sexuais estavam presentes nas crianças desde muito cedo e que independiam de qualquer estímulo do mundo externo para agirem ${ }^{18,19}$. Foi necessário algum tempo para que o próprio Freud assimilasse esta descoberta. No seu trabalho "A sexualidade na etiologia das neuroses" (1898) e mesmo no "A interpretação dos sonhos" (1900), ainda há relatos ambivalentes sobre a sexualidade infantil 20. Ao escrever o caso Dora em 1901, fica claro que Freud já tinha convicção sobre uma teoria sobre a sexualidade, porém esta aparece sistematizada somente em 1905 quando publica o trabalho "Os três ensaios sobre a teoria da sexualidade"21,22.

Resumidamente, Freud, neste trabalho, parte das aberrações sexuais, como as denominava na época, e descobre que a pulsão sexual humana é originalmente perversa e que, através de modificações orgânicas e inibições psíquicas ao longo da evolução do indivíduo, desemboca no comportamento sexual normal. Situa na infância a origem deste polimorfismo sexual: "... a pulsão sexual do adulto nasce mediante a conjugação de diversas moções da vida infantil numa unidade, numa aspiração com um alvo único"22.

Esta sexualidade infantil inicia quando a pulsão é projetada na superfície do corpo como um prurido, uma ação específica, como o dar de mamar, por exemplo, substituindo este prurido pela satisfação, vindo assim a constituir-se em uma zona erógena ${ }^{23}$. Estas zonas erógenas seguem uma evolução filogeneticamente determinada.

A primeira organização sexual é a oral, na qual os objetivos sexuais e de ingesta de alimentos não estão separados, sendo a mucosa oral a zona erógena correspondente. A seguir, tem-se a organização anal com seu fim passivo de excitação da mucosa anal e seu fim ativo de controle sádico do objeto. Nesta fase, vê-se a polarização entre o ativo e o passivo, porém ainda sem uma ligação entre ativo e masculino de um lado e passivo e feminino de outro. As fezes são tratadas como parte do corpo e significam para a criança algo muito valioso que vai ser presenteado aos pais. Este presente transforma-se, em fantasia, num bebê, com a teoria de que este é adquirido pela alimentação e nasce via intestinal. Também as fezes, ao preencherem o canal anal, configuram-se no protótipo do que posteriormente será o preenchimento da vagina pelo pênis.

Até aqui o desenvolvimento sexual entre meninos e meninas não mostra qualquer diferença. É somente a seguir, na fase fálica, que as diferenças mostram-se evidentes. Nesta etapa, Freud apresenta sua visão intensamente ligada à primazia do falo, tão importante em sua teoria sobre a sexualidade, quanto questionada posteriormente.

A fase fálica inicia-se tanto na menina quanto no menino por uma atividade masturbatória ligada aos órgãos genitais. É deste período a teoria sexual infantil que diz respeito a que tanto meninas quanto meninos possuem pênis.

O menino, em função de suas ansiedades castratórias, num primeiro momento, vê a mãe como possuindo um pênis, o que funciona como um atrativo sexual desta. Ao mesmo tempo, pelo estímulo visual, vai constatando que as mulheres não têm este pênis imaginado. Mantém esta crença, entendendo o clitóris como um pequeno pênis que irá crescer; somente mais tarde é que poderá fazer frente à idéia aterrori- 
zante, pela ameaça de castração conseqüente, de que as mulheres não têm um pênis e que este pode ter-Ihes sido cortado. A partir de então, passa a temer a mesma punição e a perda de sua masculinidade. O resultado é uma polarização entre o masculino, que detém 0 pênis, e o feminino, como um ser castrado.

Pela castração, o menino enfrentaria e resolveria seu conflito edípico, tanto na sua forma positiva, ameaçado de castração pelo pai, quanto na sua forma negativa, pelo temor de se transformar num ser castrado como a mãe $\mathrm{e}^{24,25,26}$. Instala-se como herdeiro do complexo de Édipo um severo superego ${ }^{27}$

Na menina, a evolução da fase fálica também inicia com a fantasia de que as mulheres possuem um pênis. Ainda intensamente ligada à mãe, vive a fantasia de dar um filho a esta ou de gerar um filho dela ${ }^{27}$. Com a constatação de que a mãe não possui pênis e nem ela, sentese injuriada narcisicamente e invadida por uma intensa inveja do pênis. Ressente-se com a mãe por esta não possuir e nem lhe ter dado um pênis e volta-se para o pai, num primeiro momento, para recuperar este pênis perdido e, posteriormente, com o intuito de ter um bebê do pai. O bebê assume o lugar do pênis, e a atividade dá lugar à passividade. Diferente do menino, a castração na menina introduz o Édipo ${ }^{27,28}$.

A próxima etapa é a da latência, que divide a sexualidade humana em dois pólos: o prégenital e o genital. É um período de intensa repressão da sexualidade, porém que mantém latente uma quantidade muito grande de fantasias sexuais, que na puberdade voltam à tona.

A puberdade caracteriza-se por um novo incremento dos impulsos sexuais estimulados pelas alterações hormonais. Surge um novo alvo sexual para onde convergem todas as pulsões parciais sob o primado da genitalidade. $O$ prazer do órgão é substituído pela busca do objeto, e a obtenção pura e simples do prazer, agora um pré-prazer, coloca-se a serviço da função reprodutora e da descarga dos produtos sexuais. Institui-se o orgasmo genital, sendo que na mulher o clitóris é substituído pela vagina. O ativo-clitoridiano dá lugar ao passivovaginal. A masculinidade combina os fatores de sujeito, atividade e posse do pênis e a feminilidade os de objeto e passividade ${ }^{22,26}$.

Uma das questões de maior debate na psicanálise tem sido os elementos constituintes do Édipo feminino e o estabelecimento das diferenças no desenvolvimento da menina e do menino.

Em relação à inveja do pênis, Klein, posicionando-se de modo diferente de Freud, afir- ma que o desejo da menina não é o de possuir um pênis enquanto um atributo de masculinidade, mas sim de incorporar o pênis do pai, para obter deste a satisfação do desejo de fazer um filho ${ }^{29}$. Assim sendo, para a autora, este desejo é a expressão dos componentes pulsionais femininos da menina, mais do que a inveja do pênis no sentido de transformá-la em menino (tendência masculina).

Um aspecto conseqüente a este questionamento é a sugestão de vários autores quanto à existência de sensações vaginais por parte da menina, promovendo uma percepção do corpo como contendo um espaço interno, o que favoreceria o desenvolvimento de uma postura mais receptiva que no menino ${ }^{30}$.

A impossibilidade de visualizar e explorar a vagina tem importantes implicações na representação mental de seus genitais. A possibilidade de tocar e observar a vulva, o clitóris e a genitália externa pode ser o precursor da conceitualização da vagina, levando a menina a perceber seus genitais como tendo uma abertura e um espaço interno em potencial ${ }^{31}$.

A impossibilidade da percepção concreta da vagina, como é o pênis para o menino, vincula o investimento narcísico da menina a todo seu corpo, de maneira diferente do menino, que o focaliza em seus genitais. Decorre desta impossibilidade de percepção concreta da vagina o desenvolvimento de ansiedades, que podem tomar um caráter persecutório, quanto ao estado preservado ou destruído do interior do próprio corpo, com as quais a menina vê-se envolvida durante todo seu desenvolvimento. Já o menino, com a possibilidade de visualizar o próprio pênis, tem um auxílio do teste da realidade para aplacar estas ansiedades ${ }^{29}$.

Chasseguet-Smirgel não questiona a existência da inveja do pênis na mulher, como proposta por Freud, mas propõe outro sentido à mesma $^{32}$. Não seria uma reivindicação viril, mas o desejo de contrapor-se à ferida narcísica provocada pela mãe onipotente, através da possessão de algo que a faça sentir-se superior, como ocorre com o menino. Assim sendo, a inveja do pênis origina-se do desejo de separar-se da mãe a fim de tornar-se mulher. Segundo a autora: "a menina sentiria, ao mesmo tempo, inveja de um pênis e vontade de voltar-se para o pai, ajudada nesse intento por seus desejos - poderosos e fundamentalmente femininos - de libertar-se da mãe. A inveja e o desejo erótico do pênis não se contrariam, mas seriam profundamente complementares - e permitir a satisfação simbólica da primeira seria um passo para a integração do segundo"32. 
O menino não compete com seu principal cuidador - a mãe -, na configuração edipiana positiva. Isto confere uma complexidade diferente ao desenvolvimento da menina, em que as relações pré-edipianas com a mãe terão um papel fundamental. A natureza das fantasias sádicas da menina em relação a esta mãe onipotente oferecerá grande influência na possibilidade de efetuar esta separação, de ultrapassar a conflitiva edípica ${ }^{33}$.

A relação do papel das atividades masturbatórias, bem como as experiências sensoriais iniciais da criança contribuem na capacidade desta lidar com seu próprio corpo e de separarse da mãe. Diz a autora: "O conflito edípico precoce subjacente pode ser entendido como inevitavelmente levando a um ponto no desenvolvimento em que a consciência da realidade - a separação da mãe e a colisão das fantasias onipotentes da criança do papel de não rivalidade do pai em relação à mãe - tem que ser reconhecida por ambos, meninas e meninos ${ }^{34}$.

Para a menina, a possibilidade de estabelecer relações de objeto, assim como uma relação favorável com o próprio corpo, decorre da possibilidade de ver a si própria como pertencendo ao mesmo sexo da mãe - e, portanto, diferente do seu pai -, o que entra em choque com a organização narcísica anterior. É necessário ver a si mesma como tendo um corpo que não é o masculino, e isto só é possível com o abandono da fantasia de ter o amor de sua mãe para si, o que implica a noção de que há uma satisfação que a mãe só poderá obter do pai e que a menina não será capaz de substituir ${ }^{34}$.

Estes autores salientam a ligação libidinal para com o pai, muito antes do que proposto por Freud, tanto para o menino quanto para a menina. Mas enfatizam no conflito edípico, especialmente para a menina, a importância da ligação com a mãe enquanto cuidadora. É neste contexto que a ligação com o pai ocorre, promovendo um "abandono" da ligação libidinal com o mesmo, colocando uma identificação em seu lugar. Para a resolução do complexo de Édipo, é importante o abandono de ambas ligações, permitindo apenas a ligação afetiva e as identificações com ambos os pais, que levam a uma bissexualidade psíquica madura, favorecendo a capacidade de investir objetos de ambos os sexos.

A resolução destes conflitos, assim como o estabelecimento das identificações com os pais, serão aspectos de importância na constituição da identidade de gênero nuclear do indivíduo, muito embora não sejam os únicos elementos que intervêm.
Por identidade de gênero nuclear, entende-se a noção que o indivíduo tem a respeito de seu próprio sexo, não tendo implicações de papel do gênero ou relações de objeto. É um nexo central, em torno do qual serão acrescidas a masculinidade e a feminilidade ${ }^{35}$. Segundo este mesmo autor, a identidade de gênero nuclear é o resultado de:

1. Uma "força" biológica, ou seja, de um efeito, que se origina ainda intra-útero da ação hormonal que estimulará o desenvolvimento no sentido masculino ou feminino. Esta ação pode estar ligada ao estímulo cromossômico, mas fatores outros que interfiram no estímulo hormonal poderão desviar este comando genético.

2. O sexo que é atribuído ao bebê quando de seu nascimento, que está relacionado à aparência de sua genitália externa. Isto independe do desejo dos pais quanto ao sexo do seu bebê, pois independente deste desejo não há um questionamento quanto ao sexo atribuído.

3. As atitudes dos pais em relação ao sexo da criança, originadas da percepção que estes pais têm a respeito do sexo de seu bebê, e que irão construindo as percepções do mesmo a respeito do seu próprio sexo.

4. Os fenômenos biopsíquicos que estariam ligados a efeitos causados por padrões de cuidado da criança, após seu nascimento, e que irão modificando seu cérebro e comportamento. Isto ocorre através de mecanismos como condicionamento, imprinting, ou outras formas de aprendizado, de maneira que a criança não tem processos mentais que a capacitem a proteger-se da ação destes estímulos sensoriais.

5. O desenvolvimento do ego corporal que se refere às sensações, especialmente de seus genitais, que vão definindo seu físico e as dimensões psíquicas do próprio sexo.

Além da identidade de gênero nuclear, conforme referida acima, Kernberg propõe outros dois determinantes e constituintes da experiência sexual: a identidade do papel de gênero e a escolha de objeto dominante ${ }^{16}$.

Segundo o autor, a identidade do papel de gênero refere-se a diferenças bem estabelecidas nos papéis que são atribuídos a cada gênero, como uma maior capacidade verbal para as meninas e uma maior capacidade visual, espacial e matemática para os meninos. Há achados que sugerem que este comportamento na infância possa ser influenciado por fatores hormonais pré-natais, mas entende-se que, em sua maioria, os traços que diferenciarão meninos de meninas são provavelmente determina- 
dos pela cultura.

Quanto à escolha do objeto dominante, há uma relação íntima com a identidade de gênero nuclear, pois a identificação da pessoa com um gênero está intimamente ligada ao conceito de um outro gênero, incluindo o relacionamento com este outro como objeto sexual desejado ${ }^{16}$.

Ainda se fazem necessárias algumas palavras quanto ao Ciclo da Resposta Sexual Humana, no sentido de integrar os vários aspectos relativos ao desenvolvimento, que entram na constituição de cada fase deste.

O desejo é afetado pelos níveis circulantes de testosterona, não ocorrendo quando há níveis inadequadamente baixos. Mas salienta-se que estando esta condição hormonal preserva$\mathrm{da}$, este tem como determinantes os fatores cognitivo-afetivos ${ }^{16}$. Ainda segundo o mesmo autor, o desejo erótico está vinculado ao desejo de relacionamento sexual com um objeto determinado, mais especificamente, a "excitação sexual vinculada ao objeto edípico".

Já a excitação é considerada por Kernberg como um afeto específico. Diz o autor: "Parece óbvio que ela tem raízes em funções biológicas e em estruturas que servem ao instinto básico da reprodução no reino animal"'16. Descreve-a como sendo um afeto mais próximo daqueles mais complexos, não se manifestando muito cedo na vida do indivíduo. Está vinculada às primeiras experiências de prazer, mais especificamente na sensibilidade corporal ligada à relação do bebê com seus cuidadores iniciais e, posteriormente, ao estímulo das zonas erógenas. Salienta-se a vinculação destes estímulos corporais com as fantasias correspondentes a cada zona, assim como aos imprints cognitivos a eles ligados.

No orgasmo, encontramos diferenças quanto ao gênero. Uma vez que o orgasmo masculino está ligado à ejaculação, ele tem por característica a funcionalidade, sendo a satisfação ligada ao funcionamento fisiológico. Já o orgasmo feminino, estando destituído da função reprodutiva, é essencialmente erótico. Não está especificamente vinculado à zona erógena, como no masculino, ligado ao pênis, sendo imprecisa a sua localização.

\section{COMENTÁRIOS FINAIS}

Existe um tipo de peixe de águas tropicais chamado parrot fish (peixe papagaio). Ele tem uma particularidade muito interessante. Os machos não dominantes e as fêmeas são muito semelhantes em aparência. No entanto, o macho dominante (super-macho) é azul-esverdea- do, muito maior que os outros de sua espécie e é o responsável pela fertilização de todas as fêmeas do território. Ao se retirar o super-macho de seu nicho, o maior peixe restante da mesma espécie assume suas funções reprodutoras, mesmo que este seja uma fêmea. Em uma semana, o novo peixe dominante transforma-se, inclusive mudando o sexo, se necessário, e começa a sua função de reprodução. Caso o antigo super-macho seja re-introduzido no nicho, o seu substituto retorna ao seu estado inicial.

Ao se constatar a versatilidade biológica desse animal, em prol da perpetuação da espécie, deparamo-nos com inúmeras possibilidades de comparação com o ser humano. De certo que não mudamos de sexo (não de forma natural, ao menos), mas dispomos de uma plasticidade cerebral que nos capacita a uma diferenciação, não apenas dos outros animais, como também dentre os próprios seres humanos ao longo de todo o seu desenvolvimento ${ }^{36}$.

Partimos então do princípio de que temos um sistema nervoso com um substrato mais básico equivalente às espécies menos evoluídas (do ponto de vista antropocêntrico) e um mais complexo, muito provavelmente mediado pelo neocórtex. Tal aparelhagem especializada vem se refinando, a princípio sob a égide do Imperativo Reprodutivo (deixar cópias gênicas de melhor qualidade possível para perpetuação da espécie). Desenvolve-se através da relação mãe-bebê, capacitando o novo indivíduo a lidar com as suas próprias necessidades e com as exigências do meio ambiente. "Conforme avançamos na escala biológica do reino animal (particularmente quando comparamos mamíferos inferiores com os primatas e os seres humanos), as interações psicossociais entre o bebê e seu cuidador desempenham um papel cada vez mais significativo na determinação do comportamento sexual, associadas a uma relativa diminuição do controle por fatores genéticos e hormonais"16.

Poderíamos supor que esse desenvolvimento dos afetos visaria primordialmente a atender ao Imperativo Reprodutivo?

Tal interpretação seria considerada reducionista se não levasse em consideração as múltiplas conexões e redes de influências entre as partes representadas aqui nesse trabalho sob diferentes paradigmas e caso se estivesse propondo que o Imperativo Reprodutivo fosse a única ou principal razão do desenvolvimento humano. Contrariamente a isso, nossa tentativa foi apenas a de compreender o comportamento sexual, dando importância equivalente a 
todos os seus níveis, tanto biológico, quanto psíquico, enfocando o desenvolvimento de um único indivíduo, como o de toda a espécie, num ecossistema diversificado. Não sabemos a que senhor serve qualquer uma das partes, se é que existe de fato uma tal hierarquia de importância.

Passa a ser então um exercício bastante interessante tentarmos compreender determinados aspectos do desenvolvimento e do comportamento sexual sob esse prisma mais abrangente. A infidelidade, por exemplo, poderia ser considerada, levando-se em conta os aspectos evolucionistas, como "normal" ou, no mínimo, esperada, existindo em ambos os sexos e numa freqüência bastante grande. A compreensão das razões naturais da procura por prazer "fora do casamento" (impulso que leva a uma opção genética diferente) poderia, quem sabe, facilitar o enfrentamento desses acontecimentos. Sabe-se que mulheres em período fértil são biologicamente bem mais suscetíveis à infidelidade quando comparadas a elas mesmas em período não-ovulatório, e que suas preferências por homens mudam nessa fase do ciclo (busca por homens simétricos, de bons-genes) ${ }^{37,38}$. Do ponto de vista do desenvolvimento psicossexual, não seria esperada a infidelidade, considerada em nossa cultura ocidental como fruto de conflitos intrapsíquicos não elaborados.

$\mathrm{Na}$ adolescência, a partir de modificações hormonais, ficam bastante ilustrativas as tantas motivações direcionadas à atração pelo sexo oposto, com distintas manifestações em cada sexo. Observamos os comportamentos territorial, agressivo e competitivo dos rapazes, expondo-se muitas vezes ao risco, como exibição de seus atributos. Descer uma rua movimentada de skate, pegar ondas perigosas, submeter-se a brigas de gangues são alguns dos exemplos comuns em nosso meio. Nas moças, correspondem a uma atitude provocativa e atraente, do tipo balançar os cabelos, usar roupas decotadas e curtas e oferecer olhares furtivos. Podemos compreender tais atitudes como ritos de passagem, fundamentais para o indivíduo alcançar a sexualidade madura. Esta somente se torna possível na medida de um adequado investimento parental prévio, bem como de elaboração de etapas anteriores de desenvolvimento. A dicotomia do gênero observada nessas atitudes e nas fantasias ou daydreams (Cinderela X Simbá) vai surgindo ao longo de todo o processo de maturação, sendo muito influenciada pelos fatores ambientais. O ser masculino ou feminino em aspirações e em ati- cultural de cada era ${ }^{39}$.

Do ponto de vista reducionista, faltaria ainda uma peça nesse quebra-cabeça para explicar, por exemplo, por que motivos um indivíduo saudável permaneceria como casal ao lado de outro infértil, por qual outra razão que não propriamente o Imperativo Reprodutivo. Tentando compreender os aspectos mais profundos do comportamento humano, damo-nos conta de que algo mais está por trás (ou adiante) da matriz biológica, que pode ter deixado de servir exclusivamente ao Imperativo Reprodutivo, indo mais além em busca de qualidade de vida, Iongevidade e prazer, não apenas sobrevivência e continuidade da espécie.

Cada um de nós é um ser único que durante seu desenvolvimento físico e emocional atravessa "processos" muito semelhantes, mas também com diferenças muito significativas, principalmente no desenvolvimento sexual. As características genéticas de cada indivíduo, nossas vivências, nossas sensações e emoções tornam-nos absolutamente distintos. Tem sido uma tarefa árdua do ser humano o controle dos impulsos mais básicos em prol da evolução e da civilização. Talvez exatamente por essa força de vontade é que tenhamos nos distinguido e sobrevivido como espécie.

\section{REFERÊNCIAS BIBLIOGRÁFICAS}

1. Darwin C. The descent of man and selection in relation to sex. Murray.London, England., 1871.

2. Kacelnik A. Sexualidade e biologia. In: Pellanda, NMC, Pellanda, LEC (eds) O olhar biológico. Vozes, Petrópolis, 1996, 671-689.

3. Trivers R. Parental investment and sexual selection. In: Campbell B (ed) Sexual selection and the descent of man. 1871-1971. Aldine-Atherton, Chicago, 1972, 136179.

4. Flores RZ. Um filhote de primata. Rev Psiquiatr Rio Gd Sul 19, 1997, 124-129.

5. Buss DM, Schmitt DP. Sexual strategies theory. An evolutionary perspective on human mating. Psychol Rev 100, 1993, 204-232

6. Buss DM. The evolution of disere. Strategies of human mating. BasicBooks, New York, 1994.

7. Buss DM. Sex differences in human mate preferences. Evolutionary hypothesis tested in 37 cultures. Behav Brain Sci 12, 1989, 1-49.

8. Gangestad SW, Simpson JA. The evolution of human mating. Trade-offs and strategic pluralism. Behav Brain Sci 234, 2000, 573-587 discussion 587-644.

9. Gangestad SW. Human sexual selection, good genes, and special design. Ann N Y Acad Sci 907, 2000, 50-61.

10. Pawlowski B. Dunbar, R.I. Impact of market value on human mate choice decisions. Proc R Soc Lond B Biol Sci 266, 1999, 281-285.

11. Moore KL. Embriologia Clínica. $4^{\underline{a}}$ edição. Rio de Janeiro: Editora Guanabara, 1990.

12. Guyton AC. Tratado de Fisiologia Médica. $8^{a}$ edição. Rio de Janeiro: Editora Guanabara, 1992. 
13. Kaplan H. Transtornos do Desejo Sexual. Porto Alegre: Artmed, 1999.

14. Schiavi R, Segraves RT. The Biology of Sexual Function.The Psychiatric Clinics of North America. Vol. 18, numero 1, pg 7-21, 1995.

15. Chedid S. Etiologia Orgânica e Mista dos Transtornos Sexuais Femininos \& Tratamento. Carmita Helena Najjar Abdo (org). São Paulo: Ed. Lemos, 1997.

16. Kernberg O. F. Psicopatologia das relações amorosas. Porto Alegre: Artes Médicas, 1995

17. McDougall J. As Múltiplas Fases de Eros: Uma Exploração Psicoanalítica da Sexualidade Humana. São Paulo: Martins Fontes, 1997.

18. Freud S. As neuroses de defesa. Vol. 3. Rio de Janeiro: Imago, 1896, 307-317.

19. Freud S. Carta 69. Vol. 1. Rio de Janeiro: Imago, 1897, 357-359.

20. Strachey J. Nota do editor inglês. Vol. 7. Rio de Janeiro: Imago, 1949, 119-122.

21. Freud S. Fragmentos da análise de um caso de histeria. Vol. 7. Rio de Janeiro: Imago, 1901, 12-117.

22. Freud $\mathrm{S}$. Os três ensaios dobre a teoria da sexualidade. Vol. 7. Rio de Janeiro: Imago, 1905, 118-228.

23. Freud S. Carta 52. Vol. 1. Rio de Janeiro: Imago, 1896, 254-259.

24. Freud $S$. Análise de uma fobia em um menino de cinco anos. Vol. 10. Rio de Janeiro: Imago, 1909, 13-154.

25. Freud S. Leonardo da Vinci e uma lembrança da sua infância. Vol. 11. Rio de Janeiro: Imago, 1910, 54-124.

26. Freud S. A organização sexual infantil. Vol. 19. Rio de Janeiro: Imago, 1923, 177-184.

27. Freud S. Conferência XXXII - Feminilidade. Vol. 22. Rio de Janeiro: Imago, 1933, 139-165.

28. Freud S. Sexualidade feminina. Vol. 21. Rio de Janeiro: Imago, 1931, 259-279.

29. Klein M. Os efeitos das situações de ansiedade arcaicas sobre o desenvolvimento sexual da menina. In: Klein M. A psicanálise de crianças. Rio de Janeiro: Imago; 1997. 213-257.

30. Squitieri LM. Problemas da sexualidade feminina: a função defensiva de determinadas fantasias a respeito do corpo. Livro Anual de Psicanálise, 2001; XV:49-63.

31. Mayer EL. 'Everybody must be just like me': observations on female castration anxiety. Int J Psycho-Anal, 1985;66:331-347.

32. Chasseguet-Smirgel J. A sexualidade feminina. Petrópolis: Vozes; 1975.

33. Kulish N, Holtzman D. Perséfone, a perda da virgindade e o Complexo de Édipo feminine Livro Anual de Psicanálise, 2000; XIV: 53-66.

34. Laufer ME. The female Oedipus complex and the relationship to the body. Psychoanal Study of the Child, 1986;41:259-276.

35. Stoller RJ. Primary femininity. In: Blum HP. Female Psychology. New York; IUP, 1976: 59-78.

36. Marx e Silva, M e cols. Revista de Psiquiatria do Rio Grande do Sul. Algumas bases neurobiológicas da compulsão à repetição e da mudança psíquica. 24 (1): 18-25, jan./abr. 2002

37. Gangestad SW, Thornhill R (1998) Menstrual cycle variation in women's preference for the scent of symetrica men. Proc Soc Lond B Biol Sci 265:927-933

38. Penton-Voak IS et al. (1999) Menstrual cycle alters face preference. Nature 388:741-742

39. Person ET. O Poder da Fantasia: como construímos nossas vidas. Rocco, Rio de Janeiro, 1997 pp 372. 218250

\section{RESUMO}

O desenvolvimento sexual masculino e feminino tem sido fonte de incontáveis questionamentos em várias áreas do conhecimento humano ao longo da história da humanidade. Diversas especialidades têm estudado o tópico da sexualidade de forma dissociada, dificultando a sua compreensão global e a abordagem terapêutica de seus transtornos. A busca de integração de diferentes teorias oriundas, tanto dos processos fisiológicos básicos que originam a vida, quanto dos campos mais complexos da psicanálise, tem sido um dos grandes desafios da prática clínica. Propõe-se, então, um artigo com o objetivo de descrever as diferenças de gênero no desenvolvimento sexual humano, à luz dos vértices biológico, psicanalítico e evolucionista, buscando-se pontes de conexão entre estes paradigmas, para uma visão mais integrada do processo de ser masculino ou feminino.

Descritores: sexualidade, diferenças de gênero, biologia, psicanálise, evolução.

\section{ABSTRACT}

Male and female sexual development has been source of many controversies through the human history. Many specialties have studied the sexuality from a disconnected point of view, raising difficulties to its integral understanding and therapeutic approach. The search for integration between physiology and psychoanalysis has been one of the major challenges in clinical practice. In this article we describe gender differences in sexual human development under the biological, psychoanalytical and evolutionary perspectives, searching connections between these paradigms in order to find a more integrated vision of male and female development.

Keywords: sexuality, gender differences, biology, psychoanalysis, evolution.

Title: Gender differences in sexual development: biologic, psychoanalytic and evolutionary paradigms integration

Endereço para correspondência:

Luciana Parisotto

Rua Padre Chagas, 185/1105

90570-080 - Porto Alegre - RS

E-mail: luparis@portoweb.com.br

Copyright $(\odot$ Revista de Psiquiatria do Rio Grande do Sul - SPRS 